\title{
Optical coherence tomography angiography in glaucoma: a
}

\section{mini-review [version 1; peer review: 2 approved]}

\author{
Kelvin H. Wan ${ }^{1,2}$, Christopher K. Leung ${ }^{2}$ \\ ${ }^{1}$ Department of Ophthalmology, Tuen Mun Eye Center and Tuen Mun Hospital, Hong Kong, China \\ ${ }^{2}$ Department of Ophthalmology and Visual Sciences, The Chinese University of Hong Kong, Hong Kong, China
}

V1 First published: 14 Sep 2017, 6(F1000 Faculty Rev):1686

https://doi.org/10.12688/f1000research.11691.1

Latest published: 14 Sep 2017, 6(F1000 Faculty Rev):1686

https://doi.org/10.12688/f1000research.11691.1

\begin{abstract}
The advent of optical coherence tomography angiography (OCT-A) provides a new opportunity to visualize the retinal vasculature in a non-invasive and dye-free manner which may help identify vascular abnormalities in glaucoma. While a reduction in retinal and optic nerve head vessel densities and blood flow indexes measured by OCTA has been demonstrated in patients with glaucoma in many studies, it is unclear whether OCT-A provides additional information for the detection and monitoring of glaucoma compared with OCT measurements such as retinal nerve fiber layer thickness, neuroretinal rim width, and ganglion cell inner plexiform layer thickness. Longitudinal studies are needed to elucidate whether vascular abnormalities detected by OCT-A are a cause or a consequence of optic nerve damage in glaucoma.
\end{abstract}

Keywords

optical coherence tomography angiography , glaucoma , retina , optic nerve head, vascular abnormalities, optical imaging

\section{Open Peer Review \\ Approval Status \\ 1 \\ 2 \\ version 1 \\ 14 Sep 2017 \\ Faculty Reviews are review articles written by the prestigious Members of Faculty Opinions. The articles are commissioned and peer reviewed before publication to ensure that the final, published version is comprehensive and accessible. The reviewers who approved the final version are listed with their names and affiliations.}

1. Gábor Holló, Semmelweis University, Budapest, Hungary

2. Ruikang Wang, University of Washington, Seattle, USA

Any comments on the article can be found at the end of the article. 
Corresponding author: Christopher K. Leung (cksleung.cuhk@gmail.com)

Competing interests: $\mathrm{KW}$ declares that he has no competing interests. $\mathrm{CL}$ has received speaker honoraria from Carl Zeiss Meditec and Heidelberg Engineering and research support from Carl Zeiss Meditec.

Grant information: The author(s) declared that no grants were involved in supporting this work.

Copyright: (c) 2017 Wan KH and Leung CK. This is an open access article distributed under the terms of the Creative Commons Attribution License, which permits unrestricted use, distribution, and reproduction in any medium, provided the original work is properly cited.

How to cite this article: Wan KH and Leung CK. Optical coherence tomography angiography in glaucoma: a mini-review [version 1; peer review: 2 approved] F1000Research 2017, 6(F1000 Faculty Rev):1686 https://doi.org/10.12688/f1000research.11691.1

First published: 14 Sep 2017, 6(F1000 Faculty Rev):1686 https://doi.org/10.12688/f1000research.11691.1 


\section{Introduction}

The recent introduction of optical coherence tomography angiography (OCT-A) has sparked interest in evaluating vascular alterations in the retina and optic nerve head $(\mathrm{ONH})$ for diagnosis, staging, and monitoring in glaucoma. OCT-A is an extension of OCT which allows non-invasive visualization of the retinal vasculature by detecting motion contrast from perfused blood vessels without the use of exogenous dye. In principle, OCT-A compares sequential B-scans acquired at the same location to detect change. As stationary structures would appear static in sequential B-scans, changes detected by OCT-A are largely attributed to erythrocyte movement in the perfused vasculatures. A number of algorithms such as split-spectrum amplitude decorrelation angiography (SSADA), OCT-A ratio analysis, and optical microangiography (OMAG) have been devised to compute blood flow measurements from the sequential B-scans ${ }^{1,2}$. Some of these measurements reported in the literature include vessel density (commonly annotated as the percentage of detected vessel area over the imaged area), flow index (a dimension-less parameter between 0 and 1 representing the average decorrelation signal), and blood flux index (the mean flow intensity in the vessel area normalized between 0 and 1 by dividing the full dynamic range of blood flow signal intensity). It is worth noting that these indexes are surrogate measures and their validity for measurement of blood flow remains to be investigated.

\section{Diagnostic performance of OCT-A measurements for glaucoma detection}

Jia and colleagues provided the first account of vascular abnormalities at the ONH measured by a swept-source OCT in glaucoma ${ }^{3}$. They showed that the optic disc flow index was reduced by $25 \%$ in glaucomatous eyes $(0.161 \pm 0.008)$ compared with healthy eyes $(0.121 \pm 0.026)$. Using a cut-off value of 0.1515 , they showed that the sensitivity and specificity for the detection of glaucoma were both $100 \%$ (the visual field mean deviation in the glaucoma group was $-3.28 \pm 4.12 \mathrm{~dB}$ ). The flow index was highly associated with visual field pattern standard deviation $\left(\mathrm{R}^{2}=0.752\right)$. The same group then evaluated the peripapillary flow index and the peripapillary vessel density for discrimination between glaucomatous and healthy eyes by using a spectral-domain OCT and reported the area under the receiver operating characteristic curve (AUC) to be 0.892 and 0.938 , respectively ${ }^{4}$. It remains controversial whether OCT-A measurements have a higher diagnostic performance for glaucoma detection compared with conventional OCT measurements such as the retinal nerve fiber layer (RNFL) thickness, neuroretinal rim width, and macular ganglion cell and inner plexiform layer thickness. Chen and colleagues demonstrated that the peripapillary blood flux index measured between the internal limiting membrane (ILM) and RNFL using OMAG and circumpapillary RNFL thickness had comparable diagnostic performance for the detection of glaucoma suspect (AUC $=0.76$ versus 0.70 , respectively) and glaucoma (AUC $=0.93$ versus 0.97 , respectively $)^{5}$. In a recent study, Rao and colleagues compared the diagnostic performance for glaucoma detection between OCT-A vessel density measurements using SSADA and OCT measurements (circumpapillary RNFL thickness, neuroretinal rim area, and ganglion cell complex [GCC] $)^{6}$. All vessel density measurements, including the radial peripapillary capillary (measured between the ILM and RNFL), the ONH segment vessel (measured from 2,000 $\mu \mathrm{m}$ above the ILM to $150 \mu \mathrm{m}$ below the ILM), and the macular superficial plexus (between the ILM to the inner plexiform layer), were found to have significantly smaller AUCs compared with OCT measurements. Discrepancies among the studies are likely attributed to the different definitions adopted and varying stages of glaucoma patients included in the analysis.

\section{OCT-A abnormality in glaucoma: primary damage or secondary change?}

Lee and colleagues hypothesized that if vascular abnormality were a consequence of optic nerve damage, it would be observed only at the area of RNFL defect ${ }^{7}$. Examining 98 primary open-angle glaucoma eyes with a localized RNFL defect, the authors demonstrated that the radial peripapillary capillary vascular abnormality detected by OCT-A using SSADA exactly coincided with the RNFL defect in both the location and the extent, suggesting that vascular change is a consequence of optic nerve damage in glaucoma. On the other hand, Chen and colleagues studied the microvasculature density (excluding the effect of large retinal vessels) and blood flux index between the ILM and RNFL measured using OMAG at the peripapillary region in glaucomatous eyes with single-hemifield visual field defects and reported that the intact visual hemifield showed reduced blood flux index and microvasculature density in eyes with glaucoma compared with healthy eyes but that no significant difference in circumpapillary RNFL thickness between the groups was detected ${ }^{8}$. While significant correlations between blood flow index/circumpapillary RNFL thickness and visual field mean deviation were observed in the normal visual hemifield in eyes with glaucoma, there was no correlation between microvasculature density/blood flux index and visual field mean deviation/ circumpapillary RNFL thickness in the abnormal visual hemifield. Yarmohammadi and colleagues showed that while radial peripapillary capillary vessel density, macular superficial vessel density, RNFL thickness, and GCC thickness were all reduced in both the affected and the intact visual hemifields in eyes with glaucoma, the strength of association with visual field sensitivity measures was stronger for vessel density measurements using SSADA compared with RNFL and GCC thicknesses?. Longitudinal studies investigating the temporal sequence of OCT-A and ONH/RNFL changes are needed to address whether the vascular changes detected by OCT-A are a cause or a consequence of optic nerve damage in glaucoma.

\section{Limitations of OCT-A}

Motion artefacts and projection artefacts are common in OCT-A. A considerable proportion of OCT-A images remain suboptimal in quality for interpretation. For example, in a study evaluating the intra-visit and inter-visit variability of vessel density measurement in primary open-angle glaucoma and ocular hypertension patients, $78.3 \%$ of the participants were excluded because of suboptimal SSADA-derived OCT-A image quality ${ }^{10}$. Poor-quality OCT-A scans are more common than poor-quality OCT scans. In a study in which both OCT-A and OCT measurements were performed by the same commercially available instrument, $17 \%$ and $29 \%$ of the OCT-A scans using SSADA were considered to have poor quality at the optic disc and the macula regions, respectively ${ }^{11}$. By contrast, only $9 \%$ of OCT scans at the optic disc region and $3 \%$ of OCT 
scans at the macula were graded as poor quality. With the currently available OCT-A instruments, the scan time typically varies from 3 to 6 seconds for a $3 \times 3$ to $6 \times 6 \mathrm{~mm}^{2} \mathrm{scan}^{12}$, which is longer than imaging the $\mathrm{ONH}$ or the macula for RNFL and ganglion cell layer/ inner plexiform layer analyses. The longer scan time in OCT-A can contribute to a higher incidence of motion artefact.

\section{Summary}

Vascular abnormalities detected by OCT-A have been consistently observed in glaucoma. However, it remains unclear whether OCT-A provides additional diagnostic information for the detection of glaucoma compared with conventional OCT measurements such as circumpapillary RNFL thickness, neuroretinal rim width, and ganglion cell inner plexiform form layer thickness. Findings from the literature comparing OCT-A and OCT measurements for the detection of glaucoma and evaluation of structure function association are divergent. The temporal sequence of vascular changes and optic nerve damage in glaucoma remains to be elucidated.

Competing interests

KW declares that he has no competing interests. CL has received speaker honoraria from Carl Zeiss Meditec and Heidelberg Engineering and research support from Carl Zeiss Meditec.

\section{Grant information}

The author(s) declared that no grants were involved in supporting this work.
1. $\mathrm{F}$ Gao SS, Jia Y, Zhang M, et al.: Optical Coherence Tomography Angiography. Invest Ophthalmol Vis Sci. 2016; 57(9): OCT27-36. PubMed Abstract | Publisher Full Text | Free Full Text | F1000 Recommendation

2. F Zhang A, Zhang Q, Chen CL, et al:: Methods and algorithms for optical coherence tomography-based angiography: a review and comparison. J Biomed Opt. 2015; 20(10): 100901.

PubMed Abstract | Publisher Full Text | Free Full Text | F1000 Recommendation

3. F Jia $Y$, Wei E, Wang $X$, et al:: Optical coherence tomography angiography of optic disc perfusion in glaucoma. Ophthalmology. 2014; 121(7): 1322-32. PubMed Abstract | Publisher Full Text | Free Full Text | F1000 Recommendation

4. $\quad F$ Liu L, Jia Y, Takusagawa HL, et al:: Optical Coherence Tomography Angiography of the Peripapillary Retina in Glaucoma. JAMA Ophthalmol. 2015; 133(9): 1045-52.

PubMed Abstract | Publisher Full Text | Free Full Text | F1000 Recommendation

5. $\quad \mathrm{F}$ Chen $\mathrm{CL}$, Zhang A, Bojikian KD, et al.: Peripapillary Retinal Nerve Fiber Layer Vascular Microcirculation in Glaucoma Using Optical Coherence Tomography-Based Microangiography. Invest Ophthalmol Vis Sci. 2016; 57(9): OCT475-85.

PubMed Abstract | Publisher Full Text | Free Full Text | F1000 Recommendation

6. F Rao HL, Pradhan ZS, Weinreb RN, et al:: A comparison of the diagnostic ability of vessel density and structural measurements of optical coherence tomography in primary open angle glaucoma. PLoS One. 2017; 12(3): e0173930.

PubMed Abstract | Publisher Full Text | Free Full Text | F1000 Recommendation
7. F Lee EJ, Lee KM, Lee SH, et al:: OCT Angiography of the Peripapillary Retina in Primary Open-Angle Glaucoma. Invest Ophthalmol Vis Sci. 2016; 57(14): 6265-70.

PubMed Abstract | Publisher Full Text | F1000 Recommendation

8. F Chen CL, Bojikian KD, Wen JC, et al.: Peripapillary Retinal Nerve Fiber Layer Vascular Microcirculation in Eyes With Glaucoma and Single-Hemifield Visual Field Loss. JAMA Ophthalmol. 2017; 135(5): 461-8.

PubMed Abstract | Publisher Full Text | F1000 Recommendation

9. $\quad \mathrm{F}$ Yarmohammadi A, Zangwill LM, Diniz-Filho A, et al.: Peripapillary and Macular Vessel Density in Patients with Glaucoma and Single-Hemifield Visual Field Defect. Ophthalmology. 2017; 124(5): 709-19.

PubMed Abstract | Publisher Full Text | Free Full Text | F1000 Recommendation

10. F Holló G: Intrasession and Between-Visit Variability of Sector Peripapillary Angioflow Vessel Density Values Measured with the Angiovue Optical Coherence Tomograph in Different Retinal Layers in Ocular Hypertension and Glaucoma. PLoS One. 2016; 11(8): e0161631.

PubMed Abstract | Publisher Full Text | Free Full Text | F1000 Recommendation

11. F Rao HL, Pradhan ZS, Weinreb RN, et al.: Vessel Density and Structural Measurements of Optical Coherence Tomography in Primary Angle Closure and Primary Angle Closure Glaucoma. Am J Ophthalmol. 2017; 177: 106-15. PubMed Abstract | Publisher Full Text | F1000 Recommendation

12. F Chen CL, Wang RK: Optical coherence tomography based angiography [Invited]. Biomed Opt Express. 2017; 8(2): 1056-82.

PubMed Abstract | Publisher Full Text | Free Full Text | F1000 Recommendation 


\section{Open Peer Review}

\section{Current Peer Review Status:}

\section{Editorial Note on the Review Process}

Faculty Reviews are review articles written by the prestigious Members of Faculty Opinions. The articles are commissioned and peer reviewed before publication to ensure that the final, published version is comprehensive and accessible. The reviewers who approved the final version are listed with their names and affiliations.

\section{The reviewers who approved this article are:}

\section{Version 1}

\section{Ruikang Wang}

Department of Bioengineering \& Ophthalmology, University of Washington, Seattle, WA, USA

Competing Interests: No competing interests were disclosed.

\section{Gábor Holló}

Department of Ophthalmology, Semmelweis University, Budapest, Hungary

Competing Interests: Gábor Holló is an unpaid consultant of Optovue and Zeiss (both companies produce OCT angiography instruments).

The benefits of publishing with F1000Research:

- Your article is published within days, with no editorial bias

- You can publish traditional articles, null/negative results, case reports, data notes and more

- The peer review process is transparent and collaborative

- Your article is indexed in PubMed after passing peer review

- Dedicated customer support at every stage

For pre-submission enquiries, contact research@f1000.com 